Chirurgia (2017) 112: 429-435

No. 4, July - August

Copyright@ Celsius

http://dx.doi.org/10.21614/chirurgia.112.4.429

\title{
Management of Breast Cancer Locoregional Recurrence
}

\author{
Silviu Cristian Voinea ${ }^{1,2}$, Angela Sandru' $^{1}$, Alexandru Blidaru ${ }^{1,2}$ \\ ${ }^{1}$ Second Department of Surgical Oncology, "Prof. dr. Al.Trestioreanu" Institute of Oncology, Bucharest, Romania \\ 2"Carol Davila" University of Medicine and Pharmacy, Department of Surgery, Oncological Surgery Chair
}

\section{Corresponding author:}

Angela Sandru, MD, PhD

Second Department of Surgical Oncology

"Prof dr Al.Trestioreanu" Institute of Oncology

Bucharest, Romania

E-mail: sandruangela@gmail.com

\section{Rezumat \\ Managementul cancerului mamar recidivat locoregional}

Recidiva în cancerul mamar reprezintã o provocare pentru clinician din cauza tratamentului nestandardizat şi necesitã de obicei o abordare multidisciplinarã. Aceasta este cheia pentru un control bun al bolii pe termen lung şi pentru un tratament cu intenție curativã. Recidiva localã în cancerul mamar poate apãrea dupã tratamentul chirurgical conservator sau dupã mastectomie iar recidiva regionalã implicã limfonodulii ipsilaterali axilari, mamari interni sau supraclaviculari. Prognosticul recidivei locale dupã tratamentul chirurgical conservator pare sã fie mai bun decât dupã mastectomie în termenii apariției metastazelor la distanțã şi a supraviețuirii globale. De asemenea, prognosticul recidivei axilare este mai bun decât cel al recidivei supraclaviculare sau mamare interne. Recidiva locoregionalã în cancerul mamar reprezintã mai degrabã un marker al apariției metastazelor decât un factor determinant al acestora. Opțiunile terapeutice pentru recidiva loco-regionalã în cancerul de sân impun decizii multidisciplinare şi din acest motiv este foarte importantã comisia oncologicã multidisciplinarã. Fiecare pacient trebuie sa primeascã cel mai bun tratament oncologic personalizat.

Cuvinte cheie: recidiva locoregionalã, tratament multimodal, marker al apariției metastazelor

\section{Abstract}

Breast cancer recurrence represents a challenge for clinicians because the management is not standardized and usually requires 
a multidisciplinary approach. This is the key for a good long term disease control and for a management with curative intent. The local recurrence in breast cancer appears after breast conserving treatment (BCT) or after mastectomy, and the regional recurrence involves the ipsilateral axillary, internal mammary or supraclavicular lymph nodes. Local recurrence prognosis after BCT seems to be better than after mastectomy regarding distant metastases occurrence and overall survival. Prognosis of axillary recurrence is better than prognosis of supraclavicular and internal mammary recurrence. Locoregional recurrence in breast cancer represents rather a marker for the appearance of distant metastases than a determinant factor for them. Management options for locoregional recurrence of cancer require multidisciplinary input decision making and for this reason the multidisciplinary tumor-board (MTD) is very important. Each patient should receive the best individualized oncologic treatment.

Key words: locoregional recurrence, multimodality treatment, marker of distant metastases

\section{Introduction}

The breast cancer recurrence is a very serious event for patient and clinician also and represents a challenge for at least two reasons: the recurrence seems to be a marker of distant metastases and its management rarely consists of just one specialty procedure, but needs a multimodality treatment. Multidisciplinary treatment is the key for a good long term disease control and for curative intent management.

Some potential theories that try to explain the development of recurrence take into account the following factors (1):

- Incomplete excision of primary tumor;

- Unrecognized multifocal or multicentric disease;

- Implantation of tumor cells at time of surgery;

- Entrapment of cells within obstructive lymphatic;

- Local implantation of systemically circulating cancer cells.

\section{Breast Local Recurrence}

Breast recurrence represents the reappearance of cancer in the remaining breast after breast conserving treatment (BCT) or in the soft tissues of the anterior chest wall after mastectomy in a patient with no evidence of disease after primary treatment. Some authors consider that tumor recurrence in less than one year after surgery has a worse prognosis and represents rather a continuation of the disease progression than an actual relapse. For this reason this type of relapse is called continuation of evolution and it is not addressed in this paper.

\section{Local Recurrence after BCT}

The incidence rate of local recurrence after BCT ranges from $10 \%$ to $22 \%$ at 10 years $(2,3,4)$ and its median time of appearance is 3-4 years (5-7 years after use of adjuvant systemic therapy) $(5,6)$.

In $5-15 \%$ of cases, local recurrence is associated with concomitant distant metastasis and in other 5-15\% of cases with regional disease. These 10$30 \%$ of patients with simultaneous regional or distant relapse have a worse prognosis than patients with isolated local recurrence $(5,6,7)$.

The appearance of a breast mass after BCT could represent a true local recurrence or a second primary tumor (a new breast cancer). Usually the differential diagnosis is very difficult, sometimes quite impossible, but the prognostic and therapeutic significance of this difference (relapse or new primary) is not clear yet.

The prognosis of local recurrence after BCT seems to be better then after mastectomy, with a lower rate of simultaneous regional recurrence or distant metastasis and a longer survival. However, the relation between local recurrence after $\mathrm{BCT}$ and survival remains 
controversial because recurrence seems to be rather an independent risk marker predictive for distant metastases than a determinant factor (cause) for metastasis occurrence $(8,9)$.

Two factors are considered principal determinants of local recurrence after BCT (10):

- margin status;

- the presence or absence of an extensive intraductal component (EIC).

BCT should aim to achieve microscopically negative margins (no tumor cells at the resection margins), although there is no direct relationship between margin width and rates of local recurrence. EIC seems to be highly predictive for local recurrence after $\mathrm{BCT}$ and is probably predictive for positive margins also.

Other contributing factors for relapse after BCT are $(11,12,13,14)$ :

- No radiotherapy;

- Age under 35;

- Tumor size greater than $2 \mathrm{~cm}$ in maximum diameter;

- The presence of lymph vascular invasion;

- High tumor grade;

- The presence of lobular carcinoma;

- Small volumes of excised breast tissue;

- No chemotherapy and/or hormonal therapy.

The standard approach for local recurrence management after BCT is mastectomy with or without immediate reconstruction of the breast. Reconstruction after mastectomy for local recurrence after BCT seems to be controversial because there are some unanswered questions:

- Which is the best: immediate or delayed reconstruction?

- Does reconstruction lead to a higher risk for a second local recurrence or not?

- Reconstruction with implants or autologus tissues? Which one provides safer and better cosmetic results?

In case of inflammatory local recurrence, systemic therapy is mandatory and only after a clinical response to therapy (disappearance of inflammatory changes) mastectomy seems to be feasible.

The patients who were treated only by surgery (no radiotherapy) can undergo either mastectomy or reexcision followed by radiation but, in this latter situation, there is also a debate: after breast reexcision and radiation would be possible an acceptable cosmetic outcome?

The most complicated situation is for the patients with local recurrence after breast conservative surgery and radiation that are not willing to undergo mastectomy. In this case breast reexcision is possible, followed or not by reirradiation of the remaining breast additional radiation.

The approach is still debatable for many reasons $(15,16)$ :

- a possible high rate of second local recurrence;

- an unfavorable cosmetic outcome;

- the uncertainty of technical feasibility of breast reirradiation (brachytherapy or external beam).

The local recurrence after $\mathrm{BCT}$ may be associated with regional recurrence (especially axillary lymph nodes). The management of the axilla depends on the following factors (1):

- Previous axillary surgery: none or sentinel lymph node (SLN) biopsy or axillary lymph node dissection (ALN);

- The initial stage of disease;

- The presence of distant metastases;

- The adjuvant therapies.

Patients with previous ALND and no clinical or imagistic evidence of regional disease need only simple mastectomy (no axillary restaging). For patients with previous negative SLN, an option could be repeating SLN biopsy. The rate of success for the new SLN procedure ranges from $63 \%$ to $100 \%$ in different published studies $(17,18,19)$. There are few questions about the possibility of axillary restaging (20,21):

- Is rate of axillary recurrence higher after repeated SLN biopsy?

- Is procedure sensitivity sufficiently high?

- What about the likelihood of aberrant drainage pattern? Is it higher than in the first procedure?

- Is lymphoscintigraphy still possible after radiotherapy?

For simultaneous distant metastases, patients with local breast recurrence need 
systemic therapy and the goal of treatment in this situation is palliation (no intent to cure).

Surgery for local relapse in a patient with concomitant distant disease is reserved only for those cases with enlarged, ulcerated, overinfected or bleeding recurrences aiming a better local control and to increase the quality of life.

Another situation is surgery for isolated symptomatic metastases for patients with a good health status. The intent of this type of surgery is also palliation (no evidences for improving survival).

Systemic therapy for patients with no evidence of distant metastases remains controversial, but should be considered, and the riskbenefit ratio must be discussed with patients . For triple negative tumors (ER negative, PR negative and HER 2 negative) chemotherapy is mandatory.

Subsequent recurrence rate after mastectomy performed for relapses after BCT ranges between $2 \%$ and $32 \%$, which is significantly lower comparative with recurrence rate after simply reexcision of relapse after BCT, that vary from $19 \%$ to $50 \%(6,22,23)$.

The 5 year local control was better for recurrences occurring more than 5 years after initial treatment ( $92 \%$ ) than within the first 5 years ( $49 \%$ ), while the 5 years overall survival (OS) ranged from $45 \%$ to $80 \%$ and the 10 years ranged from $40 \%$ to $65 \%(24,25)$.

There are some factors associated with a worse outcome for patients with local recurrence after $\mathrm{BCT}(1)$ :

- Inflammatory type of recurrence;

- Advanced stage of the primary tumor;

- Short interval between primary treatment and recurrence (short disease free interval);

- Large recurrent tumors with skin or muscle involvement;

- Multicentric tumor recurrence;

- Triple negative tumors.

\section{Local Recurrence after Mastectomy}

Local recurrence rates after mastectomy ranges from $5 \%$ to $15 \%$ at 10 years after treatment with a median time of appearance of just 2-3 years (even later, in case of systemic therapy administration) (1,5,26). Approximately $80 \%$ to $90 \%$ of local recurrences appear within 5 years after mastectomy and nearly all in the first 10 years. $(27,28)$ Association with regional recurrence occurs in $30 \%$ of cases $(29,30)$. About $50 \%$ of patients with local recurrence after mastectomy will develop earlier or later distant metastases $(28,31)$.

For this type of local recurrence, the amount of breast tissue left behind during mastectomy is the determinant factor. By comparison with local recurrence after BCT, the recurrence after mastectomy is more likely to be associated with a higher risk of distant metastases and a more unfavorable prognosis (shorter overall survival). Thus local relapse after mastectomy seems to be rather an independent predictor (risk marker) for distant metastases development than a determinant factor of their occurrence (10).

For resectable recurrence all gross disease must be excised and sometimes a type of tissue transfer procedure is necessary for wound closure: skin grafts or myocutaneous flaps. For patients no previous irradiated this type of technique is recommended for a better local control.

For patients who have had reconstruction without radiation, the removal of implants or flaps remains controversial because although future irradiation seems to be feasible it implies an increased risk of implants capsular contraction or even autologous flaps contraction.

The majority of recurrences after mastectomy occur in patients that had both mastectomy and radiotherapy, and in this case, surgery remains standard of care because reirradiation induces a significant risk of tissue damage and is technically difficult to perform. $(32,33)$

In the presence of concomitant distant metastases, patients are subjected to systemic therapy (chemotherapy and hormonal therapy). Conversely in the absence of distant metastases the use of systemic therapy remains debatable because of the small documented benefit on OS rate.

In literature there are described few other alternatives for treating local recurrence after 
mastectomy and radiation, such as $(34,35$, $36,37)$ :

- hyperthermia (the temperatures ranges from 40 to $45 \mathrm{C}$ );

- photodynamic therapy (FDT);

- intraarterial regional chemotherapy;

- electrochemotherapy.

These techniques are new, controversial and are not yet a real alternative to surgery and radiotherapy.

For patients with resectable isolated local recurrence after mastectomy (no regional or distant metastasis) OS rate ranges from 35\% to $80 \%$ at 5 years and $25 \%$ to $60 \%$ at 10 years (25). The 5 and 10 years actuarial rates of OS are $50 \%$ and $26 \%$ (38).

Some factors seem to influence survival after local recurrence treatment in patients with mastectomy $(29,38,39)$ :

- short free relapse interval;

- advanced stage of disease;

- axillary lymph nodes invasion;

- high tumor grade;

- age under 35 years;

- triple negative tumors;

- no prior adjuvant treatments.

\section{Regional Recurrence in Breast Cancer}

Regional recurrence in breast cancer represents the reappearance of cancer to the regional lymphatic basins in a pacient with no evidence of disease after primary treatment.

Incidence rate for regional recurrence in breast cancer, isolated or associated with local recurrence, ranges from $1 \%$ to $10 \%(40,41)$. It seems that regional relapse has increased with current use of SLN biopsy.

If there are no concomitant distant metastases, the management has curative intent. For patients who had a previous SLN biopsy, only a complete ALND is recommended. For patients who had a previous ALND, excision of the relapse is mandatory. Surgery in case of axillary recurrence can be very difficult because of the possible invasion of different axillary structures like muscles, vessels or nerves.

After complete resection of the axillary recurrence in a patient with no previous axillary radiation, radiotherapy is highly recommended because the risk of a secondary axillary relapse is high. In patients with mastectomy and no previous radiation, adding radiotherapy provides a better local control.

A real challenge is represented by patients who have had prior radiation on the axilla and incomplete excision of recurrence because repeating axillary irradiation is not usually technically feasible (1). For unresectable axillary relapses, systemic therapy and radiation are recommended only for patients without history of radiation; for patients who had already have radiotherapy, a possible solution could be reirradiation.

The prognosis of patients with axillary recurrence is better than for those with supraclavicular or internal mammary relapses (lower risk for distant metastasis and higher overall survival) (42). The management of supraclavicular and internal mammary recurrences involves systemic therapy, irradiation and sometimes surgery for diagnostic or curative goal, but the outcome is poor despite the treatments.

\section{Conclusions}

Newer treatments options require newer standard of care for primary tumor and recurrence also. Management options for breast cancer locoregional recurrence requires multidisciplinary input in decision making.

The multidisciplinary tumor-board (MTB) became very important, encompassing members from different disciplines: surgery, plastic surgery, medical oncology, radiation oncology, imaging, pathology and general practice. The communication between its members is vital for implementation of an individualized management plan for each patient with breast locoregional relapse because every patient should receive the best possible individualized care.

It seems that large multicentric randomized trials will be necessary in the future to define more precisely the factors influencing the occurrence and further evolution of breast cancer locoregional recurrence and also for better understanding the recurrence prognostic 
significance (marker or determinant factor for distant metastases), in order to establish an initial therapeutic strategy that significantly reduces the risk of relapse.

\section{References}

1. Management of Breast Cancer Recurrence. In: Michael S Sabel, ed. Essentials of Breast Surgery, First Edition. Mosby Elsevier; 2009. p. 307-322.

2. Fisher B, Anderson S, Redmond CK, Wolmark N,Wikerbam DL, Cronin WM. Reanalysis and results after 12 years of followup in a randomized clinical trial comparing total mastectomy with lumpectomy with or without irradiation in the treatment of breast cancer. New Engl j Med. 1995;333(22):1456-61.

3. Wapnir IL, Anderson SJ, Mamounas EP, Geyer CE Jr, Jeong JH, Tan-Chiu E, et al. Prognosis after ipsilateral breast tumor recurrence and locoregional recurrences in five national surgical Adjuvant Breast en Bowel Project node-positive adjuvant breast cancer trials. J Clin Oncol. 2006;24(13):2028-37.

4. Kurtz JM, Amalric R, Brandone H, Ayme Y, Jacquemier J, Pietra JC et al. Local recurrence after breast-conserving surgery and radiotherapy. Frequency, time course and prognosis. Cancer. 1989; 63(10):1912-7.

5. van Dongen JA, Voogd AC, Fentiman IS, Legrand C, Sylvester RJ, Tong D, et al. Long-term results of a randomized trial comparing breast-conserving therapy with mastectomy: European Organization for Research and Treatment of Cancer 10801 trial. J Natl Cancer Inst. 2000;92(14):1143-50.

6. Dolberg K, Mattsson A, Sandelin K, Rutqvist LE. : Outcome of treatment for ipsilateral breast tumor recurrence in early stage breast cancer. Breast Cancer Res Treat. 1998;49(1):69-78.

7. Abner AL, Recht A, Eberlein T, Come S, Shulman L, Hayes D, et al. Prognosis following salvage mastectomy for recurrence in the breast after conservative surgery and radiation therapy for earlystage breast cancer. J Clin Oncol. 1993;11(1):44-8.

8. Fisher B, Anderson S, Fisher FR, Redmond C, Wickerham DL, Wolmark N, et al. Significance of ipsilateral breast tumor recurrence after lumpectomy. Lancet. 1991;338(8763):327-31.

9. Chauvet B, Reynaud-Bougnoux A, Calais G, Panel N, Lausac J, Bougnoux $\mathrm{P}$, et al. Prognostic significance of breast relapse after conservative treatment in node-negative early breast cancer. Int $\mathrm{J}$ Radiat Oncol Biol Phys. 1990;19(5):1125-30.

10. Querci Della Rovere G, Warren R, Benson JR. Local recurrence following breast conservation treatment in early breast cancer: from screening to multimodality management. Second Edition. Taylor \& Francis; 2006. p. 389-408.

11. Kurtz JM, Jacquemier J, Amalric R, Brandone H, Ayme Y, Hans D, et al. Risk factors for breast recurrence in pre and postmenopausal patients with ductal cancers treated by conservation therapy. Cancer. 1990;65(8):1867-78.

12. Borger $\mathbf{J H}$. The impact of surgical and pathological findings on radiotherapy of early breast cancer. Radiother Oncol. 1991;22(4): 230-6.

13. Perez CA. Conservation therapy in T1-T2 breast cancer: past, current issues, and future challenges and opportunities. Cancer $\mathrm{J}$. 2003;9(6):442-53.

14. Mirza NQ, Vlastos G, Meric F, Buchholz TA, Esnaola N, Singletary SE, et al. Predictors of locoregional recurrence among patients with earlystage breast cancer treated with breast conserving treated with breast-conserving therapy. Ann Surg Oncol. 2002;9(3):256-65.

15. Deutsch M. Repeat high-dose external beam irradiation for inbreast tumor recurrence after previous lumpectomy and whole breast irradiation. Int J Radiat Oncol Biol Phys. 2002;53(3):687-91.

16. Alm El-Din MA, Feng JK, Taghian AG. Lumpectomy and partial breast irradiation for early stage-breast cancer following monthle irradiation for Hodkin's lymphoma. Nat Clin Pract Oncol. 2008; 5(7):426-9. doi: 10.1038/ncponc1135. Epub 2008 May 20.

17. Dinan D, Nagle CE, Pettgnie J. Lymphatic mapping and sentinel node biopsy in women with ipsilateral second breast carcinoma and history of breast and axillary surgery. Am J Surg. 2005; 190(4):614-7.

18. Newman EA, Cimmino VM, Sabel MS, Diehl KM, Frey KA, Chang $A E$, et al. Lymphatic mapping and sentinel lymph node biopsy for patients with local recurrence after breast-conservation therapy. Ann Surg Oncol. 2006;13(1):52-7. Epub 2006 Jan 1.

19. Barone JL, Feldman SM, Estabrook A, Tartter PI, Rosenbaum Smith SM, Boolbol SK. Reoperative sentinel lymph node biopsy in patients with locally recurrence breast cancer. Am J Surg. 2007; 194(4):491-3

20. Koizumi M, Koyama M, Tada K, Nishimura S, Miyagi Y, Makita M, et al. The feasibility of sentinel node biopsy in previously treated breast. Eur J Surg Oncol. 2008;34(4):365-8. Epub 2007 May 25.

21. Schrenk P, Tausch C, Wayand W. Lymphatic mapping in patients with primary or recurrent breast cancer following previous axillary surgery. Eur J Surg Oncol. 2008;34(8):851-6. Epub 2007 Dec 26.

22. Voogd AC, Peterse JL, Crommelin MA, Rutgers EJ, Botke G, Elkhuizen $\mathrm{PH}$, et al. Histological determinant for different types of local recurrence after breast-conserving therapy of invasive breast cancer. Dutch study Group of local recurrence after Breast Conservation (BORST). Eur J Cancer. 1999;35(13):1828-37.

23. Salvadori B, Marubini E, Miceli R, Conti AR, Cusumano F, Andreola $S$, et al. Reoperation for locally recurrent breast cancer in patients previously trated with conservative surgery. Br J Surg. 1999; 86(1):84-7.

24. Kurtz JM, Jacquemier J, Amalric R, Brandone H, Ayme Y, Hans D, Bressac C, Spitalier JM. Is breast conservation after local recurrence feasible? Eur J Cancer. 1991;27(3):240-4.

25. Gary M Freedman, Barbare L Fowdle.Local recurrence after breast conserving therapy and radiation.Oncology Jurnal. Breast cancer, nov 012000.

26. Buchanan CL, Dorn PL, Fey J, Giron G, Naik A, Mendez J, et al. Locoregional recurrence after mastectomy: incidence and outcomes. J Am Coll Surg. 2006; 203(4):469-74. Epub 2006 Aug 17.

27. Donegan WL, Perez-Mesa CM, Watson FR. A biostatistical study of locally recurrent breast carcinoma. Surg Gynecol Obstet. 1966; 122(3):529-40.

28. Tennvall-Nittby L, Tengrup I, Landberg T. The total incidence of loco-regional recurrence in a randomized trial of breast cancer TNM stage II. The South Sweden Breast Cancer Trial. Acta Oncol. 1993;32(6):641-6.

29. Gilliland MD, Barton RM, Copeland EM 3rd. The implication of local recurrence of breast cancer as the first site of therapeutic failure. Ann Surg. 1983;197(3):284-7.

30. Andry G, Suciu S, Vico P, Faverly D, Andry-t'Hooft M, Verhest A, et al. Locoregional recurrences after 649 modified radical mastectomies: incidence and significance. Eur J Surg Oncol. 1989;15(6):476-85.

31. Fentiman IS, Matthews PN, Davison OW, Millis RR, Hayward JL. Survival following local skin recurrence after mastectomy. $\mathrm{Br} J$ Surg. 1985;72(1):14-6.

32. Chen KK, Montague ED, Oswald MJ. Results of irradiation in the treatment of locoregional breast cancer recurrence. Cancer. 1985; 56(6):1269-73.

33. Laramore GE, Griffin TW, Parker RG, Gerdes AJ. The use of electron beams in treating local recurrence of breast cancer in previously irradiated fields. Cancer. 1978;41(3):991-5.

34. Schuh M, Nseyo UO, Potter WR, Dao TL, Dougherty TJ. Photodynamic therapy for palliation of locally recurrent breast carcinoma. J Clin Oncol. 1987;5(11):1766-70.

35. Sperduto PW, DeLaney TF, Thomas G, Smith P, Dachowski LJ, Russo A, et al. Photodynamic therapy for chest wall recurrence in breast cancer. Int J Radiat Oncol Biol Phys. 1991;21(2):441-6. 
36. Görich J, Hasan I, Majdali R, Sittek H, Kunze V, Doma A, et al. Previously treated, locally recurrent breast cancer: treatment with superselective intraarterial chemotherapy. Radiology. 1995;197(1): 199-203.

37. Heller R, Jaroszeski MJ, Reintgen DS, Puleo CA, DeConti RC, Gilbert RA, et al. Treatment of cutaneous and subcutaneous tumors with electrochemotherapy using intralesional bleomycin. Cancer. 1998;83(1):148-57.

38. Aberizk WJ, Silver B, Henderson IC, Cady B, Harris JR. The use of radiotherapy for treatment of isolated locoregional recurrence of breast carcinoma after mastectomy. Cancer. 1986;58(6):1214-8.

39. Deutsch M, Parsons JA, Mittal BB. Radiation therapy for local- regional recurrent breast carcinoma. Int J Radiat Oncol Biol Phys. 1986;12(12):2061-5.

40. Carpenter R, Royle GT, Cross M, Hamilton C, Buchanan R, Taylor I. Loco-regional recurrence and survival after wide local excision, radiotherapy and axillary clearance for early breast cancer. J R Soc Med. 1992;85(8):454-6.

41. Graversen HP, Blichert-Toft M, Andersen JA, Zedeler K. Breast cancer: risk of axillary recurrence in node-negative patients following partial dissection of the axilla. Eur J Surg Oncol. 1988;14(5):407-12.

42. Recht A, Pierce SM, Abner A, Vicini F, Osteen RT, Love SM, et al. Regional nodal failure after conservative surgery and radiotherapy for early-stage breast carcinoma. J Clin Oncol. 1991;9(6):988-96. 